УДК 372.881 .1

\author{
Т. О. Дороніна, С. А. Бузько
}

\title{
ШКІЛЬНІ ПІДРУЧНИКИ 3 УКРАЇНСЬКОЇ МОВИ В АСПЕКТІ ГЕНДЕРНОЇ ЗБАЛАНСОВАНОСТІ
}

Дороніна Т. О., Бузько С. А. Шкільні підручники з української мови в аспекті гендерної збалансованості.

У статті подано аналіз шкільних підручників з української мови в аспекті гендерної збалансованості. Зокрема, звернено увагу на частотність використання творів відомих письменників / письменниць; особливості відтворення на сторінках підручників образів чоловіків / жінок; наявність матеріалів, тематика яких має гендерне забарвлення.

Ключові слова: гендерний аналіз, гендерна диспропорція, гендерні стереотипи, гендерна збалансованість.

Доронина Т. А., Бузько С. А. Школьные учебники по украинскому языку в аспекте гендерной сбалансированности.

В статье представлен анализ учебников по украинскому языку в аспекте гендерной сбалансированности. В частности, обращается внимание на частотность использования произведений известных писателей / писательниц; особенности воссоздания на страницах учебников образов мужчин / женщин; наличие материалов, тематика которых имеет гендерную окрашенность и пр.

Ключевые слова: гендерный анализ, гендерная диспропорция, гендерные стереотипы, гендерная сбалансированность.

Doronina T. A., Buzko S. A. Ukrainian textbooks in the aspect of gender balance.

The article is devoted to the analysis of Ukrainian textbooks in the aspect of gender balance. In particular it pays attention to the frequency of use of the works of famous men writers / women writers, peculiarity of reconstruction of men / women's images on the pages of the textbooks, availability of materials, which subject has gender color, etc.

Key words: gender analysis, gender disparity, gender stereotypes, gender balance.

Серед проблем, які залишаються актуальними у вітчизняній системі освіти, є проблема створення підручників. За підручником залишається значення провідного засобу навчання, тому в освітній царині тривають дискусії щодо змісту, структури та вимог до сучасного підручника. Існує велика кількість теоретичних напрацювань щодо цього (А. Артюнов, Н. Басай, В. Беспалько, В. Бейлінсон, Н. Бібік, Н. Бориско, Н. Галькова, Л. Занков, Д. Зуєв, Я. Кодлюк, О. Коломінова, І. Лернер, 3. Микитенко, В. Редько, О. Савченко, Н. Скляренко та ін.).

- 275 - (C) Т. О. Дороніна, С. А. Бузько, 2012. 
Сучасні науковці розглядають підручник як комплексну інформаційну модель, яка відтворює педагогічну систему: учитель підручник - навчальний процес - учень (В. Безпалько [2]). У дослідженнях В. Бейлінсона та Д. Зуєва [1] підручник постає як системне утворення, яке поєднує в собі предметний зміст (основи наук) і види пізнавальної діяльності учнів. Вітчизняними методистами підручник розглядається як сукупність текстових та ілюстративних компонентів, які складають довідково-супровідний апарат та навчальний зміст підручника в єдину цілісну систему передачі навчальної інформації, як важливу соціально-історичну категорію, оскільки зміст освіти визначається саме державою. Отже, можна цілком справедливо стверджувати, що зміст підручника $€$ відтворенням змісту освіти на певному соціальноісторичному етапі розвитку держави [8; 10].

Метою написання статті став аналіз шкільних підручників 3 української мови в аспекті гендерної збалансованості. Упровадження гендерного компоненту до вітчизняної освітньо-виховної системи вимога часу, яка визначається сучасними євро-інтеграційними процесами, коли перед працівниками освіти 3 особливою гостротою ставиться вимога щодо формування нової особистості учня, вільної від стереотипних уявлень та упереджень, що мають будь-який дискримінаційний характер. Успішне розв'язання цього завдання залежить від багатьох чинників, зокрема від наявності в освітніх закладах гендерно збалансованої навчальної літератури.

Методика проведення гендерної експертизи підручників та іншої навчальної літератури вже розроблялася деякими сучасними вченимипедагогами. Аналіз навчальної літератури дозволив дослідникам виявити гендерну диспропорцію як у змістовній, так і в ілюстративній частинах багатьох шкільних підручників. Так, за спостереженнями деяких учених, у багатьох випадках відзначається «фемінізація навчального матеріалу, недостатність, або навіть відсутність чоловічих образів, гендерна стереотипізація. У підручниках домінують переважно жіночі образи матері-берегині, бабусі, часом згадується дідусь, а образ батька майже відсутній» [4, с. 16].

Проведення гендерного аналізу навчальних підручників, на думку Н. Городнової, можливе з урахуванням особливості побудови навчальної ситуації як «суми рівноправної взаємодії трьох суб'єктів - 
Учня, Учителя та Автора підручника» [7, с. 13]. Науковець звертає увагу на особливості пізнавальних процесів, коли «окрім отримання прямого цільового продукту (знань), завжди виникають побічні результати, які за своїми масштабами та значущістю можуть переважати передбачуваний ефект знань. Нині загальновизнано, що побічним результатом, який свідомо чи несвідомо закладається авторами-упорядниками в зміст шкільних підручників, $\epsilon$ певні гендерні стереотипи, що нав'язуються підліткам через приклади, інтерпретацію певних подій, ілюстративний матеріал, граматичні та синтаксичні конструкції тощо» [7, с. 13].

Звернення до наукової літератури $з$ цієї проблеми дає підстави стверджувати, що чільне місце під час гендерної експертизи шкільного підручника займає описовий аналіз. Головну увагу при цьому зосереджено на репрезентації жінок та чоловіків на сторінках навчальних програм, у підручниках, у змісті текстів та заголовків. Приміром, науковцями аналізується професійна представленість жінок та чоловіків, яка відтворює наявну професійну сегрегацію. Крім того, звертається увага на характер ілюстрацій («Чоловіки, хлопчики на ілюстраціях зображені енергійними, активними, жінки та дівчатка пасивними, залежними, кимось опікуваними» [6], на наявність «сексизму в ілюстраціях» (Т. Барчунова) та характер опису жінок та чоловіків (наприклад, О. Марущенко вказує, що «діяльність, успіхи і досягнення представниць жіночої статі інтерпретуються як менш значущі, менш масштабні» [9]. Також учені використовують контентаналіз, доцільність якого при проведенні гендерної експертизи підручників доведено вітчизняними науковцями (Т.Говорун, О. Кікінежді, В. Гайденко, Н. Городнова, I. Предборська та ін.). Науковці виділяють два головні різновиди контент-аналізу - кількісний (змістовий) та якісний (структурний). Перший бере до уваги зміст повідомлення (про що говориться), другий - контекст повідомлення (як говориться), що дозволяє виявити також латентну інформацію, яку несе в собі текст. Крім того, цей метод передбачає врахування невербальної інформації (ілюстрації, схеми, таблиці тощо).

Під час проведення аналізу підручників з української мови ми звертали увагу на авторство (належність жінкам чи чоловікам) як самих підручників, так і використаних у них фрагментів науково-популярних та літературно-художніх творів; особливості відтворення образів жінок та чоловіків (опис зовнішності, особистісні характеристики, характер

- 277 - Т. О. Дороніна, С. А. Бузько, 2012. 
суспільної та професійної діяльності); частотність використання творів відомих письменників / письменниць тощо.

3' ясувалося, що з 10 підручників української мови, які було взято на аналіз, авторами є переважно жінки, що, очевидно, певною мірою відповідає представленості жінок / чоловіків у мовознавчій науці також (70\% і 30\%).

У підручнику О. Глазової та Ю. Кузнєцова для 5-го класу [5]. У відтворенні образів жінок та чоловіків простежується певна тенденційність. Так, мистецтвом (танці, співи) однаковою мірою займаються i чоловіки/хлопці, i жінки/дівчата, але прикладне мистецтво (гончарство, різьбярство), тобто продуктивна праця, подається як справа включно чоловіків. Саме чоловіки позиціонуються як видатні громадські діячі та воїни. Етикетні норми спілкування також пояснюються через чоловічі образи (розмова батька 3 сином) [5, с. 27]. Натомість жіночі образи поетизуються (дівчинка 3 птахом, дівчинка ворожить на ромашці). Суспільні уявлення про традиційну роль жінок/ чоловіків представлені через казкові персонажі (чоловіки оберігають, допомагають, рятують).

У підручнику для 6 класу (автори - М. Пентилюк та ін.) дівчата представлені в однакових із хлопцями обставинах (разом співають, вчаться, ходять до бібліотеки та займаються спортом), однак уже дорослі жінки зображені виключно в родинному колі (родинна прогулянка - с. 8 ; родинне свято - с. 114; приїзд у село до бабусі c. 258). Отже, майбутнє дівчини / жінки уявляється авторами підручника обмеженим виключно родинним життям.

У підручниках для 7-го, 8-го та 9-го класів нами також було помічено гендерну диспропорцію. Так, 3-поміж видатних державних діячів, діячів науки та культури згадуються лише чоловіки, натомість жінки показані як представниці не надто престижних професій (наприклад, продавець чи касир [14, с. 8]. Крім того, представлені в аналізованих підручниках образи чоловіків демонструють більш широку (порівняно із жінками) соціальну активність: вони - вчені, музиканти, історичні діячі, математики та авіатори; саме чоловіки активно займаються спортом [16, с. 235]. Жіночі образи відтворені переважно в родинному колі [16, с. 11] або під час виконання обслуговуючої праці (наприклад, робітниці магазину) [16, с. 314, 334].

У підручнику для 10-11-го класу [17] гендерна збалансованість також, на жаль, відсутня. Наприклад, нами було помічено 9 посилань (․ Т. О. Дороніна, С. А. Бузько, 2012. 
на чоловіків-письменників, і лише одне - на жінку-письменницю. Чоловіки в цьому підручнику показані вченими, філософами, керівниками (напр., с. 85, 109).

Наступним критерієм нашого аналізу став характер добору авторами підручників навчального матеріалу, а саме частотність використання цитат із творів відомих письменників/ письменниць. Результати вивчення цього аспекту узагальнені в Діаграмі 1.

Діаграма 1

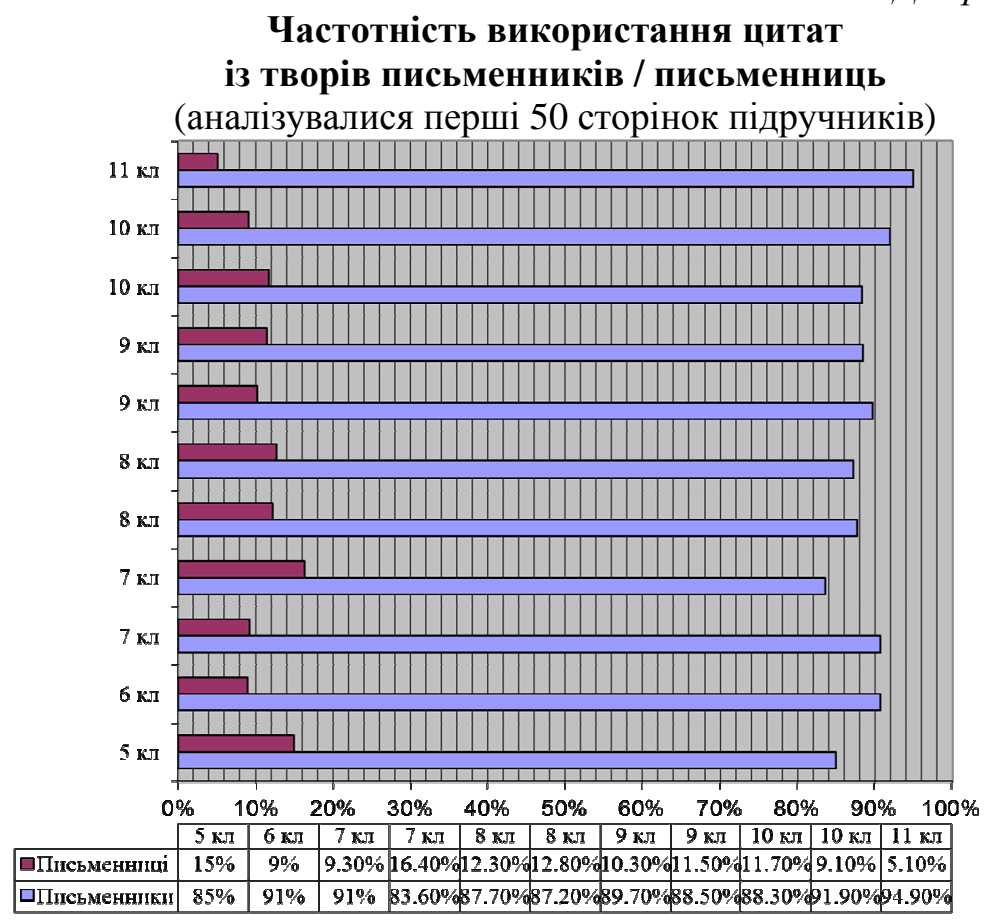

Наведені дані не лише відтворюють гендерну асиметрію, яка присутня у вітчизняному соціокультурному просторі, але й свідчать про те, що якоюсь мірою учням навіюється хибне уявлення про малозначущість жіночого внеску в розвиток суспільства, науки та культури, порівняно з чоловічим.

Про відтворення в змісті підручників гендерних стереотипів свідчить і ряд інших прикладів, як-от: у підручнику для 7-го класу гендерні

- 279 - Т. О. Дороніна, С. А. Бузько, 2012. 
стереотипи відтворюються навіть у прислів'ях (Де хата не метена, там дівка не плетена, впр. №94), а також у текстах, що подають опис краси природи (напр., про сонце: Колись, запевняють старі люди, соние світило яскравіше, бо його вранці чистила та вмивала дівчина-красуня... Сонще ж без служниці занудьгувало... (впр. №148) [12, с. 77]. Акцент ніби робиться на тому, що покликання дівчини / жінки - бути служницею.

Наявні в підручниках і ознаки професійної сегрегації. Так, справою жінок уважається вишивання (впр. №57, 71, 73), розпис (впр. №60); чоловічою - гончарство (впр. №126, 131, 132) та інші види ремісництва (впр. №128). Чоловіки тут змальовані як королі та князі, магнати та меценати; космонавти, майстри, капітани, науковці та спортсмени, режисери та педагоги, поети та письменники; медики та археологи; жінки - це просто дівчата, бабусі, матусі, дружини. Хоч у поодиноких випадках згадуються жінки-художниці (К. Білокур, М. Примаченко майстрині петриківського розпису) i лише одна жінка-лікарка. А пояснення, що таке «гостинність», робиться через посилання - «хатня робота - справа жіноча» (впр. №254).

Подібні приклади містяться в іншому підручнику з української мови також для 7 класу [11]. Професійна діяльність чоловіків представлена тут досить широко; чоловік за професією - філософ, державний діяч (напр., родовід П. Могили у вправі №39), журналіст, редактор, музикант, машиніст, солдат, учений, лікар, поет. А жінка змальовується як дочка, сестра, мати (напр., до матері тулиться дитина $[11$, c. 36], мати читає листа зі сльозами $[11$, с. 36], схиляється над колискою [11, с. 37], пече хліб [11, с.78]) або бабуся, переважно без вказівки на професійну зорієнтованість. Або ж змальовуються жінки лише як «мудрi, посивілі вчителі», що «виховували у дітей любов до рукодільництва, господарювання» [11, с. 21].

Стереотипне уявлення про те, що дівчата більш старанні у навчанні та присвячують йому більше часу, відтворюється у розмові двох подруг (впр. №231), одна з яких дивується, коли встигає вчитися брат іншої:

- I коли тільки твій брат уроки вчить? - дивується Зіна. Зранку в иколі, вдень у футбол ганяє, а ввечері, сама знаєш, від телевізора не відходить.

- Мабуть, уночі, - трохи подумавши, каже Зоя.

- Та невже? - не перестає дивуватися Зіна. - Вночі ж спати треба!

- А він на уроках висипається! - сміється Зоя [11, с. 70]. 
Підручник для 8-го (автори - О. М. Бєляєв та ін.) [13] також містить приклади гендерної асиметрії. Учні дізнаються, що саме чоловіки є митцями (впр. №23), льотчиками (впр. №56), спортсменами (с. 28), вченими-археологами (впр. №64), інженерами (впр. №34), послами (с. 35), письменниками (с. 35), моряками (впр. №190) та альпіністами (впр. №208). Також чоловік - філософ (впр. №82, с. 42), авіаконструктор (с. 64), шофер (с. 219) та громадський діяч (впр. № 213). Жінка ж у текстах більшості вправ знову представлена лише в колі родинних стосунків - як мати («лист від матерi», с. 33; «Проводжає сина мати захищати рідний край», с. 35), бабуся («Спочатку бабуся садила картопл», с. 42), сестра.

Отже, у шкільних підручниках неодмінно присутне стереотипізоване суспільне уявлення (часто - латентне) про життєве призначення чоловіків та жінок. На жаль, у більшості випадків такі уявлення свідчать про гендерну незбалансованість самого суспільства.

Привернув нашу увагу в плані гендерної диспропорції також підручник для 8-го класу (автори - А. А. Ворон, В. А. Солопенко [14]). Тексти запропонованих тут вправ містять розповіді про видатних діячів (чоловіків!) науки та культури (вправи №26, 39, 118, 133, 166, 167, 170, 180, 181, 182, 191, 211, 225, 263, 276, 302, 308, 324, 353, 373, 377). I згадується лише одна постать відомої жінки - художниці Марії Примаченко (вправа №18). Однак уже перше речення свідчить про андроцентричність мови підручника: «Марія Овксентіївна Примаченко - майстер украӥнського «наӥвного мистецтва» [14, с. 10]. Чоловіки, згадувані в текстах вправ (№391, 393), постають пророками та борцями: Максим Рильський «проголошує», Тарас Шевченко «таврує царизм», Платон Воронько «закликає», Іван Франко «пророкує» та стає «велетнем у изарстві людської культури». I лише одна жінка - Леся Українка - показана як непересічна особистість, для якої слово - «меч» (№391, 392).

У текстах на морально-етичну тематику також змальовані переважно чоловічі образи. Як, наприклад, у тексті «Шляхетність» (вправа № 254), де приклади шляхетної поведінки демонструють знову-таки чоловіки винахідник радіо Олександр Попов та польській педагог Януш Корчак.

Гендерні стереотипи відтворено також у вправі № 34; за змістом цієї вправи, учні розглядають картину, на якій зображений князь Олег iз дружиною. Досить показовим є уривок, коли діти шукають на картині зображення князевої дружини:

- 281 - С Т. О. Дороніна, С. А. Бузько, 2012. 
- Вона десь, видно, позаду, - врешті вирішив Ванько.

Сонька не була б Сонькою, коли б не заперечила:

- I зовсім не позаду! Вона вдома залишилася: князеві борш варить [14, с. 21].

Підручник для 9-го класу [16] також відтворює гендерні стереотипи сучасного суспільства. Так, у текстах вправ жінка, навіть будучи хворою, турбується за трьох своїх дітей (впр. №1), вчить дітей (впр. №22); співає колискову (впр. №58), розповідає дітям казки (впр. №175) тощо. Тобто в підручнику відтворюється стереотипне уявлення про жінку-матір, призначення якої полягає лише в народженні та вихованні дітей. Щодо професійної реалізації жінок, то в підручнику згадується лише одна «жіноча» професія - вчителька (впр. №48; 174). Єдиною жінкою, про «дивовижну долю» якої розповідається більш докладно, $є$ Роксолана, яка полонила турецького султана красою та талановитістю (впр. №204). У наступній вправі (№207) йдеться про героїв-чоловіків («могутніх велетнів»), які воювали на Запорізькій Січі (Богдан Хмельницький, Іван Сірко, Петро Сагайдачний, максим Кривоніс, Данило Нечай, Іван Богун). Однак є вправа, де йдеться про мужність та патріотизм жінок («Українські рослини символи», впр. №268): «У народі живуть легенди про сміливих дівчат, які заводили у непрохідні хащзі загони Батия, припікаючи їх на загибель. Саме з крові цчих самовідданих патріоток ніби й зросли калинові кущіџ» [15, с. 117].

Чоловіки в родинному колі змальовуються на сторінках підручників дуже рідко, акцент зазвичай робиться на їх суспільній ролі, як, наприклад, у підручнику для 10-11-го класу ([17]): чоловіки - це мужні козаки та воїни (впр. №10; 140), князі (впр. №42); великі філософи та полководці (впр. №344), відомі художники та видатні письменники (впр. №10, 397); матроси (впр. №40), пілоти (впр. №55); учені (впр. №218) тощо. Натомість жінка, як правило, постає як берегиня, господиня (впр. №226), мати (впр. №288). Доволі часто на сторінках підручників поетизується образ жінки, яка страждає, наприклад, образ жінки-вдови ([17] №130); образ матері, яка втратила свого сина ([17] №197).

У підручниках для старших класів тексти вправ подають відомості про життєвий і творчий шлях відомих чоловіків (учених та митців), наприклад, про творчі пошуки видатного вченого Володимира Вернадського ([17], впр. №114); письменника й режисера Олександра Довженка ([17], впр. № 122); поета Василя Стуса ([17], впр. №93); письменника Михайла Коцюбинського ([17], впр. №110); живописця-

(ㄱ Т. О. Дороніна, С. А. Бузько, 2012. 
пейзажиста Архипа Куїнджі ([17], впр. № 219); найвідомішого графіка Якова Гніздівського ([17], впр. №277), філософа Григорія Сковороди ([17], впр. №318). І вкрай рідко згадується про жінок, які присвятили себе творчій діяльності (напр., Марія Башкирцева ([17], впр. №33), яку представлено як співачку та художницю).

Проведений аналіз шкільних підручників із української мови дає підстави стверджувати, що ілюстративний матеріал цих підручників відтворює гендерні стереотипи та культурні норми, що відображають гендерну матрицю суспільства. Очевидним $\epsilon$ те, що гендерні стереотипи відтворюють панівний у суспільстві тип соціальної взаємодії чоловіків і жінок; характер їхньої репрезентації у суспільній та приватній сферах; суспільні стандартизовані уявлення про моделі поведінки (ролі) чоловіка / жінки в суспільстві. У зв'язку з цим важливим видається питання подолання гендерних стереотипів, що є доволі дискусійним і таким, що потребує подальшої наукової розробки.

\section{Література}

1. Бейлинсон В. Г. О функциональном подходе к оценке школьных учебников / В. Г. Бейлинсон, Д. Д. Зуев // Проблемы школьного учебника - М. : Просвещение, 1977. - Вып. 5. - С. 42-54.

2. Беспалько В. П. Теория учебника: дидактический аспект / Владимир Павлович Беспалько. - М. : Педагогіка, - 1988. - 160 с.

3. Бондаренко Н. В. Українська мова : [підручник для 10 класу загальноосвітніх навч. закладів з рос. мовою навчання] / Н. В. Бондаренко. - К. : Грамота, 2010. -288 с.

4. Гайденко В. «Мама мила раму», або Проблема відображення гендерної рівності в підручниках початкової школи // В. Гайденко // Початкова освіта. - 2004. - №19. C. 16-17.

5. Глазова О. П. Рідна мова : [підруч. для 5 кл. загальноосвіт. навч. закл.] / О. П. Глазова, Ю. В. Кузнєцов. - К. : Освіта, 2005. - 288 с.

6. Говорун Т. Гендерна дискримінація в сфері освіти [Електронний ресурс] / Т. Говорун, О. Кікінежді. - Режим доступу : http://www.helsinki.org.ua/index.php?id=1200305760.

7. Городнова Н. М. Соціально-психологічні чинники становлення статеворольової ідентифікації підлітків : автореф. дис. на здобуття наук. ступеня канд. психолог. наук : спец. 19.00.07 «Педагогіка та вікова психологія» / Н. М. Городнова. K., 2006. $-24 \mathrm{c}$.

8. Карпенко О. Основні вимоги до навчальної інформації в сучасному підручнику [Електронний ресурс] / О. Карпенко // Педагогіка, психологія та медико-біологічні проблеми фізичного виховання і спорту. - 2007. - №2. - Режим доступу : http://www.nbuv.gov.ua/portal/Soc_Gum/ppmb/texts/2007-02/07keaimt.pdf

9. Марущенко О. А. Шкільні навчальні програми з історії у фокусі гендерного аналізу [Електронний ресурс] / О.А. Марущенко // Вісник Міжнародного слов'янського університету : український науково-теоретичний журнал. - 2008. T. 11. - №2. - C. 37-41. 
10.Редько В. До проблеми сучасного шкільного підручника іноземної мови [Електронний pecypc] / В. Редько. - Режим доступу : http://bibl.kma.mk.ua/pdf/zbirnuku/11/1.pdf

11. Українська мова : [підручник для 7 класу загальноосвітніх навч. закладів з рос. мовою навчання] / О. М. Бєляєв, М. І. Пентилюк, Л.М. Симоненкова, Т. П. Симоненкова. - К. : ВД «Афон», 2004. - 128 с.

12. Українська мова : [підручник для 7 класу загальноосвітніх навч. закладів з рос. мовою навчання] / О. М. Горошкіна, А. В. Нікітіна, Л. О. Попова. - К : Ін-т сучас. підруч., 2007. - 176 с.

13. Українська мова : [підручник для 8 класу загальноосвітніх навч. закладів 3 рос. мовою навчання] / О. М. Бєляєв, М. І. Пентилюк, Л. М. Симоненкова, Т. П. Симоненкова. К. : ВД «Афон», 2004. - 136 с.

14. Українська мова : [підручник для 8 класу загальноосвітніх навч. закладів 3 навчанням рос. мовою] / А. А. Ворон, В. А. Солопенко. - К. : Освіта, 2008. - 272 с.

15. Українська мова : [підручник для 9 класу загальноосвітніх навч. закладів з рос. мовою навчання] / О. М. Бєляєв, М. І. Пентилюк, Л. М. Симоненкова, Т. П. Симоненкова. [3-те вид., пер. і доп.]. - К. : Освіта 2002. - 208 с.

16.Українська мова : [підручник для 9 класу загальноосвітніх навч. закладів 3 навчанням рос. мовою] / Н. В. Бондаренко, А. В. Ярмоленко. - К. : Освіта, 2009. - 383 с.

17. Українська мова : [підручник для 10-11 класу загальноосвітніх навч. закладів 3 навчанням рос. мовою] / О. М. Бєляєв, Л. М. Симоненкова, Л. Д. Скуратівський, Г. Т. Шелехова. - [4-е вид.]. - К. : Освіта, 2001. - 240 с.

Стаття надійшла до редакції 02.10.2012 p. 